University of Nebraska - Lincoln

DigitalCommons@University of Nebraska - Lincoln

Faculty Publications, Department of Child, Youth, and Family Studies

Child, Youth, and Family Studies, Department of

$6-2012$

\title{
Portuguese Translation and Validation of the Revised Dyadic Adjustment Scale
}

\author{
Cody S. Hollist \\ University of Nebraska-Lincoln, chollist2@unl.edu \\ Olga G. Falceto \\ Universidade Federal do Rio Grande do Sul \\ Luciane M. Ferreira \\ Universidade Federal do Rio Grande do Sul \\ Richard B. Miller \\ Brigham Young University, rick_miller@byu.edu \\ Paul R. Springer \\ University of Nebraska-Lincoln, pspringer3@unl.edu \\ See next page for additional authors
}

Follow this and additional works at: https://digitalcommons.unl.edu/famconfacpub

Part of the Developmental Psychology Commons, Family, Life Course, and Society Commons, Other Psychology Commons, and the Other Sociology Commons

Hollist, Cody S.; Falceto, Olga G.; Ferreira, Luciane M.; Miller, Richard B.; Springer, Paul R.; Fernandes, Carmen L. C.; and Nunes, Nalu A., "Portuguese Translation and Validation of the Revised Dyadic Adjustment Scale" (2012). Faculty Publications, Department of Child, Youth, and Family Studies. 87. https://digitalcommons.unl.edu/famconfacpub/87

This Article is brought to you for free and open access by the Child, Youth, and Family Studies, Department of at DigitalCommons@University of Nebraska - Lincoln. It has been accepted for inclusion in Faculty Publications, Department of Child, Youth, and Family Studies by an authorized administrator of DigitalCommons@University of Nebraska - Lincoln. 


\section{Authors}

Cody S. Hollist, Olga G. Falceto, Luciane M. Ferreira, Richard B. Miller, Paul R. Springer, Carmen L. C. Fernandes, and Nalu A. Nunes 


\title{
Portuguese Translation and Validation of the Revised Dyadic Adjustment Scale
}

\author{
Cody S. Hollist, PhD \\ University of Nebraska-Lincoln \\ Olga G. Falceto, MD, \& Luciane M. Ferreira, MD \\ Universidade Federal do Rio Grande do Sul \\ Richard B. Miller, PhD \\ Brigham Young University \\ Paul R. Springer, PhD \\ University of Nebraska-Lincoln \\ Carmen L. C. Fernandes, MD \\ Groupo Hospitalar Conceição \\ Nalu A. Nunes, MS \\ Brigham Young University

\begin{abstract}
Corresponding author - Cody S. Hollist, Department of Child, Youth and Family Studies,
University of Nebraska-Lincoln, 130 Mable Lee Hall, Lincoln, Nebraska 68588; email chollist2@unl.edu
\end{abstract}

\begin{abstract}
The absence of a translated and validated instrument for measuring marital satisfaction in Brazil, the largest country in South America and fifth most populous country in the world, is a significant barrier for research and mental health service delivery. The purpose of this study was to translate and validate a marital satisfaction scale into Portuguese that would have both empirical credibility and cultural relevance in Brazil. A sixstep serial approach was used to simultaneously translate and culturally validate the Revised Dyadic Adjustment Scale (RDAS). The translated instrument (RDAS-P) demonstrated good psychometric properties during field testing.
\end{abstract}

The quality of marital relationships has been demonstrated to be an important indicator of adult, couple, and child well-being. There is considerable evidence that low marital quality is a significant risk factor for mental health symptoms (Kouros, Papp, \& Cummings, 2008). For example, adults in distressed marriages are significantly more likely to become depressed (Whisman, 2001). Moreover, research has linked low marital quality to poorer physical health (Kiecolt-Glaser \& Newton, 2001). Not only predictive of self-reported global health (Umberson, Williams, Powers, Liu, \& Needham, 2006) but also low marital quality has been shown as a risk factor for specific diseases, such as ulcers (Levenstein, Kaplan, \& Smith, 1995), hypertension (Wickrama et al., 2001), cardiovascular diseases (Smith \& Glazer, 2005), and atherosclerosis (Gallo et al., 2003). One outcome related to the impact on health is reflected in the higher use of medical services by adults who report low marital quality (Sandberg, Miller, Harper, Robila, \& Davey, 2009).

Treatment research has also found a relationship between marital quality and mental health outcomes. The most significant literature to illustrate this is regarding depression and marital quality. Research has shown a strong link between relationally focused couples therapy and decreases in depression symptomatology (Beach, 2001; Kung, 2000). Couple's therapy has also been shown to be effective when working with couples dealing with different forms of trau- 
matic stresses (Johnson, 2002). Among these, forms of trauma are child sexual abuse (MacIntosh \& Johnson, 2008) and couples with a chronically ill child (Gordon Walker, Johnson, Manion, \& Cloutier, 1996). Research has even shown that couples-based treatments have an impact on quality of life for couples dealing with chronic illnesses, such as cancer (Baik \& Adams, 2010).

Extending the impact of poor marital quality beyond the couple, research has illustrated the impact it has on children (Krishnakumar \& Buehler, 2000). There is evidence that low marital quality is predictive of internalized child behaviors, such as depression and anxiety, as well as externalized child behaviors, such as delinquency and sexually acting out (Zimet \& Jacob, 2001).

Central to clinical and basic marital research is the availability of psychometrically sound instruments to assess marital quality. In addition, reliable and valid instruments are essential in providing therapists with accurate information about the quality of the relationship of couples who are in treatment (Prouty, Markowski, \& Barnes, 2000). As pointed out by Whisman, Snyder, and Beach (2009), the DSM-IV provides only vague and general criteria for assessing marital discord. Research indicates that clinical outcomes improve when therapists are given feedback during the course of therapy concerning the progress of their clients (Anker, Duncan, \& Sparks, 2009), the availability of valid marital quality instruments in clinical settings becomes even more important.

Unfortunately, there is no psychometrically validated and culturally appropriate measure of marital quality in Portuguese. Consequently, there is no opportunity for researchers to replicate basic research that examines the effect of marital distress on health, for researchers to conduct valid marital outcome studies, and for therapists to adequately assess the relationship impact of treatment for Portuguese-speaking clients, especially in Brazil.

Brazil is the fifth most populous country in the world, with over 193 million inhabitants (Instituto Brasileiro de Geografia e Estatı'stica, 2008). As Brazil's economy has grown, the number of Brazilian immigrants globally has also grown. Within the United States, census data report that there are 687,000 individuals whose primary language at home is Portuguese (United States Census Bureau, 2010). The purpose of this study was to translate and validate a marital quality instrument for use with a Brazilian Portuguese-speaking population.

\section{Methods and Results}

Merely translating an instrument from one language to another is simple, but it fails to verify the instrument's utility for the target population. Gudmundsson (2009) has argued, "A translated version of a test cannot be assumed to have the same psychometric qualities as a standardized version in the primary language" (p 29). The challenge, then, becomes how to structure the translation and validation process, so the resulting instrument is psychometrically sound and culturally appropriate.

The most common approach to translation is a three-step process of translation, back translation, and comparison of equivalence. While this may produce a linguistically accurate instrument, it does not address the cultural adaptation that is critical for valid psychological assessment. Consequently, a six-step methodological approach developed by Herrera, DelCampo, and Ames (1993), called the "serial approach to translation," was used in this study. This approach integrates cultural adaptation within the process of instrument translation.

\section{Instrument Identification}

The instrument that was translated into Portuguese was the Revised Dyadic Adjustment Scale (RDAS), which is a shortened version of the Dyadic Adjustment Scale (DAS). The DAS developed by Spanier (1976) is one of the most popular measures of marital quality, having been used in hundreds of studies since it was developed (South, Krueger, \& Iacono, 2009). It is a 32-item instrument that produces both a total score for marital quality and scores for four subscales: Dyadic Satisfaction, Dyadic Cohesion, Dyadic Consensus, and Affectional Expression. An important characteristic of the DAS is that the subscales provide additional clinical 
utility. Because the instrument approaches assessment from four vantage points (i.e., the subscales), it provides a greater range of specificity in its evaluative properties. This strengthens the accuracy of the outcomes and also gives clinicians a specific direction related to areas of relational strength and weakness.

While the DAS has been used extensively, research has identified some doubt about the psychometric adequacy of the factor structure of the DAS. Sharpley and Cross (1982) found that, although the overall scale has adequate validity and reliability, most of the 32 items were unnecessary and that factor analysis failed to reproduce the four subscales that were developed by Spanier (1976). Another study (Kazak, Jarmas, \& Snitzer, 1988) also failed to find statistically significant evidence for the four subscales. Although other studies found support for the Consensus, Cohesion, and Satisfaction subscales, a meta-analysis of 91 published studies found that the Affectional Expression subscale failed to produce adequate Cronbach's alpha scores (Graham, Liu, \& Jeziorski, 2006).

In response to these growing concerns, Busby, Christensen, Crane, and Larson (1995) shortened the DAS and eliminating the Affectional Expression subscale. They called it the RDAS. The instrument was shortened to 14 items with three remaining subscales, Consensus, Cohesion, and Satisfaction. The revised measure was more highly correlated than the DAS with the Locke-Wallace Marital Adjustment Test (Locke \& Wallace, 1959), which is another popular measure of marital quality. It was equally accurate in discriminating distressed and nondistressed couples, with scales correctly classifying $81 \%$ of the cases. Confirmatory factor analysis found strong support for three subscales (Consensus, Satisfaction, and Cohesion), and the Cronbach's alpha of the overall scale was .90 , with reliability scores of .81 for Consensus, .85 for Satisfaction, and .80 for Cohesion.

The RDAS has the advantages over the DAS of having less than half as many items and a clearer factor structure. Other short forms of the DAS have been developed, including a 7-item version, and shown to have valid psychometric properties (Hunsley, Pinsent, Lefebrve, James- Tanner, \& Vito, 1995). However, they consist of only one factor and fail to produce the multiple subscales that make the DAS particularly useful in clinical settings. Conversely, the RDAS maintains the original scale's strengths of multidimensionality. Consequently, it was chosen for translation.

Determined to develop a culturally valid instrument, investigators involved both subject matter experts as well as methodology experts from the study's inception and they continued throughout the data collection, analysis, and instrument completion process. Although not all of the experts spoke Portuguese, they were familiar with the cultural adaptation of assessment instruments. Based on the expertise of the research team, a serial approach to instrument translation was chosen (Herrera et al., 1993). In this approach, there are six stages, with each step building upon the previous and with each step focusing on both the language and the culturally appropriate conceptualization of the construct.

\section{Step 1: Collective Translation}

The objective of the first step is to produce a collectively agreed-upon translation of the original instrument. The expertise of the translators will directly affect the degree to which the final instrument measures the construct in a culturally appropriate manner. Translators need to have experience and understanding of both cultures, be fluent in both languages, and have prior experience with translation. In the process of translating the RDAS into Portuguese, five primary translators worked on the initial translation, all of whom were experts on marital relationships. All had spent time in both the United States and Brazil and were fluent in both Portuguese and English. All had mental health-related doctoral degrees (i.e., MD and PhD) and had research experience with mental health evaluations. One of the most important characteristics is that all had experience working clinically with Brazilian couples. (See Table 1 for further information about initial translators.)

The five translators independently developed what they considered to be the most accurate version of the instrument, taking into account both language and culture. With their own translations completed, they met to compare and collectively develop what they considered to be the most accurate version. 


\begin{tabular}{|c|c|c|c|c|c|c|}
\hline Gender & $\begin{array}{l}\text { Native } \\
\text { language }\end{array}$ & $\begin{array}{l}\text { Highest } \\
\text { degree }\end{array}$ & $\begin{array}{l}\text { Years } \\
\text { clinical } \\
\text { work }\end{array}$ & $\begin{array}{l}\text { Years } \\
\text { living } \\
\text { abroad }\end{array}$ & Profession & $\begin{array}{l}\text { Professional } \\
\text { practice }\end{array}$ \\
\hline $\begin{array}{l}\text { Female } \\
\qquad(\# 1)\end{array}$ & Portuguese & MD & 27 & 0 & $\begin{array}{l}\text { Community and } \\
\text { Family Medicine }\end{array}$ & $\begin{array}{l}\text { Director } \\
\text { Community } \\
\text { Medical Clinic } \\
\text { Private practice }\end{array}$ \\
\hline Female & Portuguese & MD \& & 38 & 5 & Psychiatry & Director of \\
\hline$(\# 2)$ & & $\mathrm{PhD}$ & & & & $\begin{array}{l}\text { Adolescent } \\
\text { Psychiatry at a } \\
\text { Medical School } \\
\text { Private practice }\end{array}$ \\
\hline $\begin{array}{l}\text { Female } \\
\qquad(\# 3)\end{array}$ & Portuguese & MD & 20 & 0 & Psychiatry & Private practice \\
\hline $\begin{array}{l}\text { Male } \\
(\# 1)\end{array}$ & Portuguese & MD & 37 & 7 & Psychiatry & $\begin{array}{l}\text { Private practice } \\
\text { Invited Medical } \\
\text { School Professor }\end{array}$ \\
\hline $\begin{array}{l}\text { Male } \\
(\# 2)\end{array}$ & English & $\mathrm{PhD}$ & 6 & 3 & $\begin{array}{l}\text { Marriage and } \\
\text { Family Therapy }\end{array}$ & $\begin{array}{l}\text { Assistant Professor } \\
\text { Private practice }\end{array}$ \\
\hline
\end{tabular}

While most of the items in the RDAS were consistent with Brazilian culture, one question (i.e., "How often do you calmly discuss something?") concerned some of the translators. They believed that the way the question was phrased might cause confusion among Brazilians. As the translators discussed the issue, there seemed to be a rationale for maintaining the original phraseology, as well as for changing the question. Consequently, the translation team decided to rewrite this question by slightly altering the wording of the phrase to better represent the meaning of the statement. It was believed that this new translated version was more culturally sensitive and would be better understood by Brazilian couples. However, because the study had multiple levels of validation and field testing, the research team strongly felt that both the original and the revised questions should be included in the field testing of the translated instruments. The team believed that one of these questions would be naturally eliminated through the statistical procedures and the qualitative validity interviews.

The last task of the first step was to have a native Portuguese-speaking language expert review the proposed instrument for grammatical accuracy. The Portuguese expert suggested only minor edits to improve clarity for a wider range of the couples' education level. After the grammatical check, the first draft of the instrument was completed.

\section{Step 2: Instrument Clarity}

The purpose of this step was to pilot test the newly developed instrument on samples of monolingual Brazilian couples. These interviews were conducted in a medium-sized city in southern Brazil. There were five individuals, all natives of that region of Brazil, who participated in the interviews.

Because the intent of this step was to determine understandability and not outcome generalizability, a convenience sampling method was used. Investigators wanted to interview both men and women, with a range of ages, income levels, and educational levels. Two of the participants were men, and three were women; none had traveled outside of Brazil, and none spoke any other language than Portuguese. All five had graduated from high school, but only two of them had attended college. Two individuals, one man and one woman, were from poor families and one individual, a woman, was from an affluent family. Ages ranged from the early 20 s to the late 50 s. 
The interviews were conducted by two investigators, both bilingual, with one whose primary language was English and one whose primary language was Portuguese. After participants read each question, the interviewers asked them whether the question seemed unclear. The interviewers then asked them to explain what they thought the question was asking and what part of their couple interaction it was asking about. They were finally asked whether they felt this question reflected an important part of their relationship.

These interviews resulted in only a few minor changes, with exception of the item that had been a concern among translators. Participants expressed confusion with the original translated question. Conversely, they confirmed that the modified question was a more clear way to ask about how well they communicated as a couple. Neither item was removed at this time because of methodological decision that both qualitative and quantitative steps would be used to determine the most useful phraseology.

The next set of interviews was conducted by administering the instrument orally. The research team deemed it important to determine whether the instrument could be responded to by someone who was unable to read the questionnaire. The questions were read aloud to four married participants from southern Brazil, none had graduated from high school but two of them were able to read. After reading the question, participants were asked what they thought the question meant. They were also asked to identify whether there were any questions that were confusing or unclear. Again, with exception of the one item, only minor concerns were expressed. These concerns were similar to those expressed by the sample who read the instrument.

Following both sets of pilot interviews, the translators met again to discuss the implications of the changes that were identified and to determine whether it would impact the meaning of the items. The determination was made to change some of the words to more simple and clear terms to enhance understandability.

\section{Step 3: Back Translation}

With a clearly translated instrument, the next step was back translation. Five bilingual individuals, who were neither healthcare providers nor involved in any other portion of the study, translated the Portuguese version of the instrument back into English. Of the five, two had some graduate education, two had some college education, and one had only a high school degree. Two were native English speakers and three native Portuguese speakers. While the wording of the original English version and the back-translated version had minor linguistic differences, the intent and meaning were consistent. The results did not highlight any need for further changes.

\section{Step 4: Field Testing}

The fourth step involved field testing. The first phase of field testing was to collect data needed to determine the consistency between translated instruments through test-retest comparisons. Three bilingual and monolingual groups were given the original English version of the RDAS, the Portuguese version of the RDAS-P, or both. The three groups used were monolingual English speakers $(N=15)$, monolingual Portuguese speakers $(N=15)$, and bilingual speakers $(N=38)$. As suggested by Carrol, Holman, Segura-Bartholomew, Bird, and Busby (2001), care was taken to ensure that the bilingual group was comprised of individuals whose native language was Portuguese and an equal number of individuals whose native language was English. For the group of bilingual participants, the instruments were randomly given in two sequences (i.e., English first or Portuguese first), to control for administration effects. For all groups, there was a 2-week interval between administrations of instruments.

A second phase was used to determine construct validity and internal consistency reliability. Data for this portion of the field testing were considered as part of a longitudinal study on family functioning in southern Brazil (see Hollist et al., 2007). The study collected data from 148 families who all had a child born during a 1-year window in 1999. All families of the identified neighborhood that had children born during that period were identified and invited to participate. Interviews were conducted when the child was 4 months old. The families par- 
ticipated in a second wave of data collection when the child was 2 years of age and in a third wave of data collection when the child was 5 years of age. Over $70 \%$ of the families that were invited to participate completed the first wave of data collection $(n=148)$. The average age of the mothers at first data collection was $26(S D=6.66)$, and the average age of the fathers was $30(S D=8.08)$. The mothers and fathers had an average of 6.6 and 7.0 years of education, respectively.

Field testing of the RDAS-P was carried out during the third wave of data collection. It was in the third wave that the RDAS-P was included in the questionnaire. Data were collected by teams of two family therapists, who administered instruments and conducted clinical evaluations. While there were 126 families that participated in wave-3, only 77 of the families had intact couples as heads of household. Both partners completed the RDAS-P, resulting in 77 men and 77 women completing the field testing for the instrument.

\section{Step 5: Psychometric Testing}

The fifth step was to use the collected data to test the psychometric properties of the RDASP. Prior to calculating reliability and validity, it was necessary to make a final determination concerning which of the two items in question to eliminate. Analyses compared the two items with the other items in the instrument, as well as the overall score from the other 13 items. The qualitative interviews, as well as the statistical results, validated the concerns of the translators in favor of removing the directly translated item. Consequently, the original item was removed, and the revised item was included in the scale (See Appendix A for the final translated version of the RDAS-P).

Test-Retest Reliability. The first form of reliability evaluated was test-retest reliability. This was calculated from data collected in the first phase of field testing. The test-retest evaluation was used to determine measurement specificity across time. When using test retest in the translation process, if the baseline test-retest reliability is high and the bilingual test-retest correlation indices are low, this usually indicates translation problems (Carrol et al., 2001). Thus, if the translation is accurate, scores across groups will be similar.

The results of the test-retest reliability indicated that there was good consistency between instruments. The correlation of scores for the two administrations of the instrument for the monolingual English group was $r=.89(n=15, p<.001)$, and for the monolingual Portuguese group, the score was $r=.98(n=15, p<.001)$. The bilingual group comprised of both native English speakers and native Portuguese speakers who took the instrument once in English and once in Portuguese. The couples whose primary language was Portuguese had a correlation coefficient of $r=.76(n=20, p<.001)$, and those whose primary language was English scored $r=.80(n=18, p<.001)$. Each of the test-retest outcomes showed adequate consistency between test administrations.

Internal Consistency Reliability. Internal consistency reliability shows how well changes in the score for one item are reflected in changes in the score for another. This was conducted by running a Cronbach's alpha with all items of the instrument. The internal consistency reliability was computed from data collected from the 154 individuals in the Brazil community family development study. The alpha score for the complete RDAS-P was $a=.822$. Coefficients above .70 are generally considered to be good indicators of internal consistency (Juni, 2007).

Face Validity. The process of face validity was built into the translation methods. The mental health and content experts involved in the study were careful to incorporate cultural appropriateness in each step of the process. The final version of the instrument was considered by the experts to be an accurate evaluation of marital quality for couples in Brazil.

Construct Validity. Construct validity was assessed by comparing the participants in the longitudinal study RDAS scores with interviewers' assessment of the quality of the relationship. Because the interviews were conducted by native Brazilian family therapists, they were qualified to provide evaluations of the couple relationship. During data collection, each of the family therapist interviewers independently evaluated the relationship quality of the couple. The clinical evaluation was a Likert-type scale from 1 to 5 , with a higher score indicating higher marital quality. Following the interview, the therapists met and talked about their clin- 
ical assessments and arrived at a consensus as to the quality of the marital relationship. Correlations between the RDAS-P and the clinical evaluations were significant (Pearson $r=.52, p<$ .001), suggesting that the newly translated instrument has adequate construct validity.

Additional analyses were run to evaluate the relationship between psychometrics and demographic characteristics. The alpha score for women in the field testing was $a=.847$, and for men, the alpha score was a $=.802$. There were no significant differences between the psychometric properties of the RDAS-P based on age, ethnicity, or income.

\section{Step 6: Interpretation}

During the course of the translation process, face validity, construct validity, test-retest reliability, and internal consistency reliability were evaluated. These outcomes were used to determine not only the linguistics of the instrument, but also the cultural accuracy of the instrument. The outcome was an instrument that is clearly related to the theoretical and contextual intent of the developers of the RDAS (Busby et al., 1995) and, at the same time, culturally adapted for use with a Brazilian Portuguese-speaking population.

\section{Conclusion}

\section{Clinical Implications}

In addition to facilitating marital research in Brazil and other Portuguese-speaking countries, the most significant impact of the RDAS-P is for mental health providers and medical professionals. Mental health providers can use the RDAS-P as a tool to track changes in couple relationships and inform clinical decisions related to treatment approaches and termination or transferral (Anker et al., 2009; Busby, Ivey, Harris, \& Ates, 2007). Utilizing the RDAS-P as an assessment-based intervention would strengthen not only the accuracy of the outcomes, but also gives clinicians a specific direction that they can focus treatment and interventions (Prouty et al., 2000). For example, providers may use the specific items and subscales to address areas of strengths and weaknesses for the couple. Consequently, clinicians can use the RDAS-P to assess pre- and post-treatment changes, as well as track couple progress during treatment, thus becoming an important tool for clinicians to assess effectiveness.

The RDAS-P can also be used by physicians as a triage instrument to assess couples who seek medical care where relational treatment may aid their mental or physical health treatment. This would be a feasible and practical tool for family practice clinics in Brazil because of their system of socialized medicine. In fact, family practice clinics in Brazil provide the majority of mental health triage, but currently they lack valid couple assessment tools to orient treatment evaluation and delivery. The research on marital quality clearly identifies it as both a risk and a protective factor for health (Kiecolt-Glaser \& Newton, 2001); thus, clinics with a mechanism for evaluating marital quality can intervene early because of improved assessment, which may improve treatment outcomes. Further research will need to be performed to assess the impact of triage use of the RDAS-P in medical clinics in Brazil.

In addition to improved diagnoses, effective assessment of marital quality can inform more effective treatment of relational distress and the associated health, both mental (Kouros et al., 2008) and physical (Kiecolt-Glaser \& Newton, 2001). Marital quality may be used to inform prenatal care planning, comprehensive family medical plans, chronic illness treatment plans, treatment of patients that are high users of services, and other programs focused on complex and / or comprehensive treatment. Thus, this translated and validated instrument may be used by mental health professionals in evaluation and triage as well as providing a credible informant for clinical decisions.

\section{Study Limitations and Further Research}

Further research is necessary to determine the cutoff scores for the RDAS-P with the Brazilian population. The English version of the RDAS has a cutoff score that delineates distressed couples from nondistressed couples (Crane \& Middleton, 2000). The cutoff scores can then be used in triage. However, it is methodologically inappropriate to use the cutoff score from 
a different language version of an instrument (Gudmundsson, 2009). One limitation of this study and an area of further research will be the development of cutoff scores for clinical and nonclinical couples for the RDAS-P.

The study was also limited in its geographical representation of Brazil. Because the study was conducted only in the southern part of the country, it will be necessary to test the instrument in other regions to verify cultural appropriateness across areas of the country. Another limitation of the study is that the range of ethnicity and age of the participants of the field testing was limited. The primary field testing sample was from a lower-middle class neighborhood in southern Brazil who all had young children at the time of data collection. Further studies are needed to expand the generalizability of the validity of the RDAS-P for different age groups and other ethnic groups in Brazil.

The accurate assessment of marital quality can be used to improve quality of marital therapy (Busby et al., 2007), enhance treatment of depression (Beach, 2001), and facilitate basic research on the influence of marital discord on health (Kiecolt-Glaser \& Newton, 2001). This study employed a rigorous method of translation and cultural adaptation that executed several tests of reliability and validity within the Brazilian population. The resulting instrument, the RDAS-P, is believed to be an accurate evaluation of marital quality among Brazilian couples.

\section{References}

Anker, M. G., Duncan, B. L., \& Sparks, J. A. (2009). Using client feedback to improve couple therapy outcomes: A randomized clinical trial in a naturalistic setting. Journal of Consulting and Clinical Psychology, 77, 693-704.

Baik, O. M., \& Adams, K. B. (2010). Improving the well-being of couples facing cancer: A review of couples' based psychosocial interventions. Journal of Marital and Family Therapy, 37, 250-266.

Beach, S. R. H. (2001). Marital therapy for co-occurring marital discord and depression. In S. R. H. Beach (Ed.), Marital and family process in depression: A scientific foundation for clinical practice (pp. 205-224). Washington, DC: American Psychological Association.

Busby, D. M., Christensen, C., Crane, D. R., \& Larson, J. H. (1995). A revision of the dyadic adjustment scale for use with distressed and nondistressed couples: Construct hierarchy and multidimensional scales. Journal of Marital and Family Therapy, 21, 289-308.

Busby, D. M., Ivey, D. C., Harris, S. M., \& Ates, C. (2007). Self-directed, therapist-directed, and assessmentbased interventions for premarital couples. Family Relations, 56, 279-290.

Carrol, J. S., Holman, T. B., Segura-Bartholomew, G., Bird, M. H., \& Busby, D. M. (2001). Translation and validation of the Spanish version of the RELATE questionnaire using a modified serial approach for crosscultural translation. Family Process, 40, 211-231.

Crane, D. R., \& Middleton, K. C. (2000). Establishing criterion scores for the Kansas Marital Satisfaction Scale and the Revised Dyadic Adjustment Scale. The American Journal of Family Therapy, 28, 53-60.

Gallo, L. C., Troxel, W. M., Kuller, L. H., Sutton, T. K., Edmondowicz, D., \& Matthews, K. A. (2003). Marital status, marital quality, and atherosclerotic burden in postmenopausal women. Psychosomatic Medicine, 65, 952-962.

Gordon Walker, J., Johnson, S. M., Manion, L., \& Cloutier, P. (1996). Emotionally focused martial interventions for couples with chronically ill children. Journal of Consulting and Clinical Psychology, 64, 1029-1036.

Graham, J. M., Liu, Y. J., \& Jeziorski, J. L. (2006). The Dyadic Adjustment Scale: A reliability generalization meta-analysis. Journal of Marriage and Family, 68, 701-717. Gudmundsson, E. (2009). Guidelines for translating and adapting psychological instruments. Nordic Psychology, 61, 29-45.

Herrera, R. S., DelCampo, R. L., \& Ames, M. H. (1993). A serial approach for translating family science instrumentation. Family Relations, 42, 357-360.

Hollist, C. S., Miller, R. B., Falceto, O. G., \& Fernandes, C. L. C. (2007). Marital satisfaction and depression: A replication of the marital discord model in a Latino sample. Family Process, 46, 485-498.

Hunsley, J., Pinsent, C., Lefebrve, M., James-Tanner, S., \& Vito, D. (1995). Construct validity of the short forms of the Dyadic Adjustment Scale. Family Relations, 44, 231-237. 
Instituto Brasileiro de Geografia e Estatı́stica (2008). Projeção da população do Brasil (Population projection for Brazil). Comunicação Social, Novembro.

Johnson, S. M. (2002). Emotionally focused couple therapy with trauma survivors: Strengthening attachment bonds. New York: Guildford.

Juni, S. (2007). Reliability theory. In N. J. Salkind (Ed.), Encyclopedia of measurement and statistics, vol. 3 (pp. 834-835). Thousand Oaks, CA: Sage Publications.

Kazak, A. E., Jarmas, A., \& Snitzer, L. (1988). The assessment of marital satisfaction: An evaluation of the Dyadic Adjustment Scale. Journal of Family Psychology, 2, 82-91.

Kiecolt-Glaser, J. K., \& Newton, T. L. (2001). Marriage and health: His and hers. Psychological Bulletin, 127, 472-503.

Kouros, C., Papp, L., \& Cummings, E. (2008). Interrelations and moderators of longitudinal links between marital satisfaction and depressive symptoms among couples in established relationships. Journal of Family Psychology, 22, 667-677.

Krishnakumar, A., \& Buehler, C. (2000). Interparental conflict and parenting behaviors: A meta-analytic review. Family Relations, 49, 25-44.

Kung, W. W. (2000). The intertwined relationship between depression and marital distress: Elements of marital therapy conducive to effective treatment outcome. Journal of Marital and Family Therapy, 26, 51-63.

Levenstein, S., Kaplan, G. A., \& Smith, M. (1995). Sociodemographic characteristics, life stressors, and peptic ulcer: A prospective study. Journal of Clinical Gastroenterology, 21, 185-192.

Locke, H. J., \& Wallace, K. M. (1959). Short marital-adjustment and prediction tests: Their reliability and validity. Marriage and Family Living, 21, 251-255.

MacIntosh, H. B., \& Johnson, S. (2008). Emotionally focused therapy for couples and childhood sexual abuse survivors. Journal of Marital and Family Therapy, 34, 298-315.

Prouty, A. M., Markowski, E. M., \& Barnes, H. L. (2000). Using the dyadic adjustment scale in marital therapy: An exploratory study. Family Journal, 8, 250-257.

Sandberg, J. G., Miller, R. B., Harper, J. H., Robila, M., \& Davey, A. (2009). The relationship among marital quality, health, and health care utilization in older couples. Journal of Health Psychology, 14, 9-17.

Sharpley, C. F., \& Cross, D. G. (1982). A psychometric evaluation of the Spanier Dyadic Adjustment Scale. Journal of Marriage and the Family, 44, 739-747.

Smith, T. W., \& Glazer, K. M. (2005). Hostility, marriage, and the heart: The social psychophysiology of cardiovascular risk in close relationships. In D. R. Crane \& E. S. Marshal (Eds), Handbooks of families and health (pp. 19-39). Thousand Oaks, CA: Sage Publications.

South, S. C., Krueger, R. F., \& Iacono, W. G. (2009). Factorial invariance of the Dyadic Adjustment Scale across gender. Psychological Assessment, 21, 622-628.

Spanier, G. B. (1976). Measuring dyadic adjustment: New scales for assessing the quality of marriage and similar dyads. Journal of Marriage and the Family, 38, 15-28.

Umberson, D., Williams, K., Powers, D. A., Liu, H., \& Needham, B. (2006). You make me sick: Marital quality and health over the life course. Journal of Health and Social Behavior, 47, 1-16.

United States Census Bureau (2010). Language us in the United States: 2007. American Community Survey Reports, April 2010.

Whisman, M. A. (2001). The association between depression and marital depression. In S. R. H. Beach (Ed.), Marital and family processes in depression: A scientific foundation for clinical practice (pp. 3-24). Washington, DC: American Psychological Association.

Whisman, M. A., Snyder, D. K., \& Beach, S. R. H. (2009). Screening for marital and relationship discord. Journal of Family Psychology, 23, 247-254.

Wickrama, K. A. S., Lorenz, F. O., Wallance, L. E., Peiris, L., Conger, R. D., \& Elder, G. H. (2001). Family influence on physical health during the middle years: The case of onset of hypertension. Journal of Marriage and Family, 63, 527-539.

Zimet, D. M., \& Jacob, T. (2001). Influences of marital conflict on child adjustment: Review of theory and research. Clinical Child and Family Psychology Review, 4, 319-335. 


\section{Appendix A: Final Translated Version of the RDAS-P}

Nome:

Data:

\section{Escala Revisada de Ajustamento Conjugal em Portuguese (RDAS-P)}

A maioria das pessoas têm divergências nos seus relacionamentos. Por favor, indique abaixo qual o nı́vel aproximado da concordância ou divergência entre você e seu esposo(a), companheiro(a), para cada item da lista que se segue:

\begin{tabular}{|c|c|c|c|c|c|c|}
\hline & $\begin{array}{l}\text { Sempre } \\
\text { Concordamos }\end{array}$ & $\begin{array}{l}\text { Quase sempre } \\
\text { Concordamos }\end{array}$ & $\begin{array}{l}\text { As vezes } \\
\text { concor- } \\
\text { damos }\end{array}$ & $\begin{array}{l}\text { Frequen- } \\
\text { temente } \\
\text { Discor- } \\
\text { damos }\end{array}$ & $\begin{array}{l}\text { Quase } \\
\text { sempre } \\
\text { Discor- } \\
\text { damos }\end{array}$ & $\begin{array}{l}\text { Sempre } \\
\text { Discor- } \\
\text { damos }\end{array}$ \\
\hline $\begin{array}{l}\text { 1. Assuntos } \\
\text { religiosos }\end{array}$ & 5 & 4 & 3 & 2 & 1 & 0 \\
\hline $\begin{array}{l}\text { 2. Demonstrações } \\
\text { de carinho }\end{array}$ & 5 & 4 & 3 & 2 & 1 & 0 \\
\hline $\begin{array}{l}\text { 3. Tomada de } \\
\text { decisões } \\
\text { importantes }\end{array}$ & 5 & 4 & 3 & 2 & 1 & 0 \\
\hline $\begin{array}{l}\text { 4. Relações } \\
\text { sexuais }\end{array}$ & 5 & 4 & 3 & 2 & 1 & 0 \\
\hline $\begin{array}{l}\text { 5. Regras de } \\
\text { comportamento } \\
\text { social (por ex. } \\
\text { como } \\
\text { cumprimentar } \\
\text { pessoas, regras } \\
\text { à mesa, } \\
\text { vestimenta) }\end{array}$ & 5 & 4 & 3 & 2 & 1 & 0 \\
\hline \multirow[t]{2}{*}{$\begin{array}{l}\text { 6. Decisõ es } \\
\text { profissionais }\end{array}$} & 5 & 4 & 3 & 2 & 1 & 0 \\
\hline & Sempre & $\begin{array}{l}\text { Quase } \\
\text { sempre }\end{array}$ & $\begin{array}{l}\text { Mais } \\
\text { frequente- } \\
\text { mente sim } \\
\text { do que não }\end{array}$ & Às vezes & Raramente & Nunca \\
\hline $\begin{array}{l}\text { 7. Com que } \\
\text { frequêência } \\
\text { vocês conversam } \\
\text { sobre divórcio, } \\
\text { separação ou } \\
\text { terminar } \\
\text { sua relação? }\end{array}$ & 0 & 1 & 2 & 3 & 4 & 5 \\
\hline $\begin{array}{l}\text { 8. Com que } \\
\text { freqüêencia você } \\
\text { e seu esposo(a), } \\
\text { companheiro(a) } \\
\text { brigam? }\end{array}$ & 0 & 1 & 2 & 3 & 4 & 5 \\
\hline $\begin{array}{l}\text { 9. Você já se } \\
\text { arrependeu de } \\
\text { ter casado ou } \\
\text { vivido juntos? }\end{array}$ & 0 & 1 & 2 & 3 & 4 & 5 \\
\hline
\end{tabular}




\begin{tabular}{|c|c|c|c|c|c|c|}
\hline & Sempre & $\begin{array}{l}\text { Quase } \\
\text { sempre }\end{array}$ & $\begin{array}{l}\text { Mais } \\
\text { frequente- } \\
\text { mente sim } \\
\text { do que não }\end{array}$ & Às vezes & Raramente & Nunca \\
\hline \multirow{2}{*}{$\begin{array}{l}\text { 10. Com que } \\
\text { arrependeu de } \\
\text { freqüência você } \\
\text { e seu esposo(a), } \\
\text { companheiro(a) } \\
\text { se irritam muito } \\
\text { um com o outro? }\end{array}$} & 0 & 1 & 2 & 3 & 4 & 5 \\
\hline & $\begin{array}{l}\text { Todos } \\
\text { os dias }\end{array}$ & $\begin{array}{l}\text { Quase } \\
\text { Todos } \\
\text { os dias }\end{array}$ & Às vezes & Raramente & Nunca & \\
\hline $\begin{array}{l}\text { 11. Você e seu } \\
\text { esposo(a), } \\
\text { companheiro(a) } \\
\text { fazem coisas } \\
\text { juntos fora } \\
\text { de casa? }\end{array}$ & 4 & 3 & 2 & 1 & 0 & \\
\hline
\end{tabular}

Com que freqüência você e seu esposo(a), companheiro(a) fazem as seguintes atividades juntos?

\begin{tabular}{|c|c|c|c|c|c|c|}
\hline & Nunca & $\begin{array}{l}\text { Menos de } \\
\text { uma vez } \\
\text { por mês }\end{array}$ & $\begin{array}{l}\text { Uma ou } \\
\text { duas vezes } \\
\text { por mês }\end{array}$ & $\begin{array}{l}\text { Uma ou } \\
\text { duas } \\
\text { vezes por } \\
\text { semana }\end{array}$ & $\begin{array}{l}\text { Uma } \\
\text { vez por } \\
\text { dia }\end{array}$ & $\begin{array}{l}\text { Mais de } \\
\text { uma vez } \\
\text { por dia }\end{array}$ \\
\hline $\begin{array}{l}\text { 12. Trocam } \\
\text { idéias de } \\
\text { uma forma } \\
\text { estimulante? }\end{array}$ & 0 & 1 & 2 & 3 & 4 & 5 \\
\hline $\begin{array}{l}\text { 13. Fazem } \\
\text { juntos } \\
\text { alguma } \\
\text { atividade? }\end{array}$ & 0 & 1 & 2 & 3 & 4 & 5 \\
\hline $\begin{array}{l}\text { 14. Vocês têm } \\
\text { conversas } \\
\text { interessantes? }\end{array}$ & 0 & 1 & 2 & 3 & 4 & 5 \\
\hline
\end{tabular}

De: Busby, D. M., Crane, D. R., Larson, J. H., \& Christensen, C. (1995). A revision of the Dyadic Adjustment Scale for use with distressed and nondistressed couples: Construction hierarchy and multidimensional scales. Journal of Marital and Family Therapy, 21, 289-308.

\section{Scoring Instructions}

Scoring the RDAS-P follows the same procedure as the original RDAS (Busby et al., 1995). Scores are obtained by summing the individual items from the 14 questions. When administering the instrument one can remove the numeric values leaving only the location for marking the answer. However, when scoring the instrument, questions 1 through 6 are reverse coded starting at 5 and decreasing to 0 . Question 11 is also reverse coded, but the score starts with the number 4 then decreases to 0 . All other items are coded from 0 to 5 . Composite scores range from 0 to 69 with higher scores indicating greater marital satisfaction. 